Article

\title{
The Impact of Basalt Components on the Structure of Bricks Formed as a Result of Hydrothermal Treatment
}

\author{
Anna Stepien * and Paulina Kostrzewa \\ Department of Civil Engineering and Architecture, Kielce University of Technology, al. 1000-lecia PP 7, \\ 25-314 Kielce, Poland \\ * Correspondence: ana_stepien@wp.pl
}

Received: 22 July 2019; Accepted: 22 August 2019; Published: 26 August 2019

\begin{abstract}
The article focuses on brick products, the production of which is based on natural components, such as lime $(\mathrm{CaO})$, quartz sand $\left(\mathrm{SiO}_{2}\right)$ and water $\left(\mathrm{H}_{2} \mathrm{O}\right)$, and which are created during the process of the so-called hydrothermal treatment. In the production process of the modified brick, basalt components (basalt aggregate, with graining of $2-4 \mathrm{~mm}$, basalt powder and basalt fibers) were used because of their natural origin, mineralogical composition, high volume density, and possibly minimal absorbability. In the article thermodynamic properties of minerals forming the construction of basalt components were determined, as well as the phases that arise during the autoclaving process. Compressive strength and density were investigated due to acoustic properties. The product modified with basalt aggregate shows decrease in water absorption as a result of capillary action and in absorbability up to $9 \%$ (in the reference sample up to $16 \%$ ). The sample with basalt aggregate shows compressive resistance of $33 \mathrm{MPa}$ on average, with the increase of volume density to $2.29 \mathrm{~kg} / \mathrm{dm}^{3}$. Modification of sand-lime mixture presented satisfying results with $10 \%$ basalt powder additive. Application of basalt fibers slightly changed the volume density and absorbability compared with the norm sample. However, it affected the compressive resistance.
\end{abstract}

Keywords: bricks; basalt; fiber; powder; aggregate; hydrothermal condition

\section{Introduction}

The most popular building materials can be distinguished concrete and bricks as artificial stone, natural stone and wood. Autoclaved bricks are one of the most popular building materials for constructing structural walls, whose formation time is much lower than in concrete. The article focuses on brick products, the production of which is based on natural components, such as lime $(\mathrm{CaO})$, quartz sand $\left(\mathrm{SiO}_{2}\right)$ and water $\left(\mathrm{H}_{2} \mathrm{O}\right)$, and which are created during the process of the so-called hydrothermal treatment. Those raw materials create a mixture with the ingredients strictly determined by the size of molar ratio of $\mathrm{CaO} / \mathrm{SiO}_{2}(\mathrm{C} / \mathrm{S})$ that equals mostly 0.09 [1]. Building industry changes the picture of the environment the most, and it generates the human living conditions. What is advocated by the research performed by the University of Manitoba in Canada, some of the diseases of the respiratory system, including asthma (especially in the case of children) is connected with building materials, used, among others, for construction of residential buildings [2]. Thus, knowing the process of hydration reaction of lime and its hydrothermal treatment, the analysis of possible modifications was performed, the basic element of which was the fact of preserving naturality and minimizing the negative effects of material production on the environment. In the times of arising need for building materials, new solutions are being searched for, which will take safety politics into consideration, as well as balanced development, including recycling of the materials [3-6]. Nowadays, the material which is undergoing modifications the most often, is concrete of various types, among which the most popular is highly resistant concrete, destined for large-size buildings. Preserving proper proportions 
of what is produced and used, and what is connected with the phenomenon of overuse of mineral sources [7-11].

The aim of the article is to present material which fulfills construction demands in the case of a single-family residential buildings, as well as multi-family buildings (up to 5 floors) with suitable modifications, which also takes acoustic properties into consideration.

Noise level is rising radically, and it is connected not only with traffic noise, but also with the noise generated by the building industry, including construction machinery. It is noise that is blamed for human distraction and decreased productivity level in the workplace. The modification presented aims at increase in, among others, density of sand-lime material, which will improve the acoustic comfort in premises of a multi-family buildings [12-14].

According to this, in the production process of the new brick, basalt components were used because of their natural origin, mineralogical composition, high volume density, and possibly minimal absorbability. The modifier applied to the traditional sand-lime product was basalt aggregate, with graining of 2-4 mm, basalt powder and basalt fibers. In the world, other basalt substitutes are also used, such as basalt pumice (scoria), which is to be the basis for the design of light and durable concrete (SLWHSC) [15]. Kilic and others conducted studies showing that lightweight concrete (SLWC) can be produced using scoria, but the use of mineral additives seems to be mandatory in the production of SLWHSC. The use of a three-component blend has been recommended due to its satisfactory strength development and environmental friendliness (concrete with an admixture of silica dust and fly ash, which is amorphous and thermodynamically stable at room temperature and contributes to the formation of a calcium silicate hydrate (C-S-H) phase favorable for concrete production). In the case of the production of silicate bricks, the task of using basalt pumice may be difficult because the production process takes place at a temperature of $200^{\circ} \mathrm{C}$, so the dominant phase will not be C-S-H, and tobermorite. For this reason, basalt components in the form of: aggregates, fibers and dust were selected for laboratory tests.

\section{Materials and Methods}

Traditional sand-lime brick is created from lime ( $\mathrm{CaO}$ in about $7 \%$ of weight), water $\left(\mathrm{H}_{2} \mathrm{O}\right.$ in about $3 \%$ of weight) and sand $\left(\mathrm{SiO}_{2}\right.$ in about $90 \%$ of weight) thus, it is a silicate. Graining of sand equals about $0-2 \mathrm{~mm}$. The place of origin of the substrate is crucial, the so-called deposit of sand for material production. It is recommended to perform research of mineral composition of the components each time, considering their quality and possible pollution (proper reactivity of lime, content of $\mathrm{Al}$ in sand, amount of pure quartz and other minerals such as calcite or aragonite). During the production process, sand and lime, which are saturated with water vapor harden creating "artificial stone" of high resistance (approximately about $20 \mathrm{MPa}$ ). Despite many advantages (good acoustic insulation, high compressive resistance and frost resistance), research aiming at producing material of improved essential characteristics is constantly being performed. This type of material should be natural, durable and which will be recycled aggregate after its service life.

Rectangular samples (size $40 \times 40 \times 160 \mathrm{~mm}$ ) of traditional components and added modifiers were prepared in Sand-Lime Production Plant. Basalt and its derivatives were assumed as the modifiers. An important aspect of the production of this kind of building materials is the quality control of lime and the temperature during lime hydration with sand. It is preferred that it is above $80^{\circ} \mathrm{C}$.

\subsection{Basalt and Its Derivatives}

Basalt is a volcanic stone, occurring naturally. It offers specially beneficial physical qualities, high resistance to chemical and mechanical weathering, wear and proves satisfying compressive resistance. Aggregate of varied fraction, which is commonly used as construction and road material, is produced from basalt. Basalts exhibit a semi-crystalline structure, which also indicates that these components are less reactive to amorphous substrates that are components of building materials, such as fly ashes or glass fly ashes. The minerals that form the basis for the construction of basalt are 
mainly: plagioclases and pyroxenes, followed by amphiboles, melilite, biotite, quartz, tridymite or cristobalite. Depending on the source and the area of their origin and extraction, there is a different composition and the presence of other minerals such as: enamel, magnetite, graphite or even apatite, which in the last 5 years is increasingly used in construction. Thus, for example, plagioclases range from the form of albite to anorthite (from $\mathrm{NaAlSi}_{3} \mathrm{O}_{8}$ to $\mathrm{CaAl}_{2} \mathrm{Si}_{2} \mathrm{O}_{8}$, which implies that the sodium and calcium atoms can be mutually substituted and substituted in the crystal lattice that forms them. This has a significant impact on the properties of the modified material and its durability. Ca affects the alkalinity and binding of the material, while $\mathrm{Na}$ leads to the formation of natrolite and gyrolite in the material structure. [16]

Basalts are extraordinarily rich in $\mathrm{MgO}$ and $\mathrm{CaO}$ compounds, and at the same time poor in compounds such as: $\mathrm{SiO}_{2}, \mathrm{Na}_{2} \mathrm{O}$ and $\mathrm{K}_{2} \mathrm{O}$ compared with another volcanic stones. The empirical formula of basalt is determined by its geographic localization and consists of: $\mathrm{SiO}_{2}-52.8 \%$, $\mathrm{Al}_{2} \mathrm{O}_{3}-17.5 \% \mathrm{Fe}_{2} \mathrm{O}_{3}-10.3 \%, \mathrm{MgO}-4.63 \%, \mathrm{CaO}-8.59 \%, \mathrm{Na}_{2} \mathrm{O}-3.34 \%, \mathrm{~K}_{2} \mathrm{O}-1.46 \%, \mathrm{TiO}_{2}-1.38 \%$, $\mathrm{P}_{2} \mathrm{O}_{5}-0.28 \%, \mathrm{MnO}-0.16 \%, \mathrm{Cr}_{2} \mathrm{O}_{3}-0.06 \%[17,18]$. In large quantities, basalts occur in India, Russia (Siberian traps), Mongolia, Ethiopia, Brazil, Uruguay and Paraguay, Argentina (Patagonia), in America (British Columbia-Canada, Washington and Oregon-USA, as well as in Italy, on Hawaii and Iceland, while on the Polish basalt scale they are mainly found in Silesia.

The content of quartz may equal up to $20 \%$. In terms of its mineral composition, basalts consists mainly of plagioclase and diamond pryoxenes. Sometimes, also considerable amounts of olivines appear in the mineral composition (Figure 1) [19].

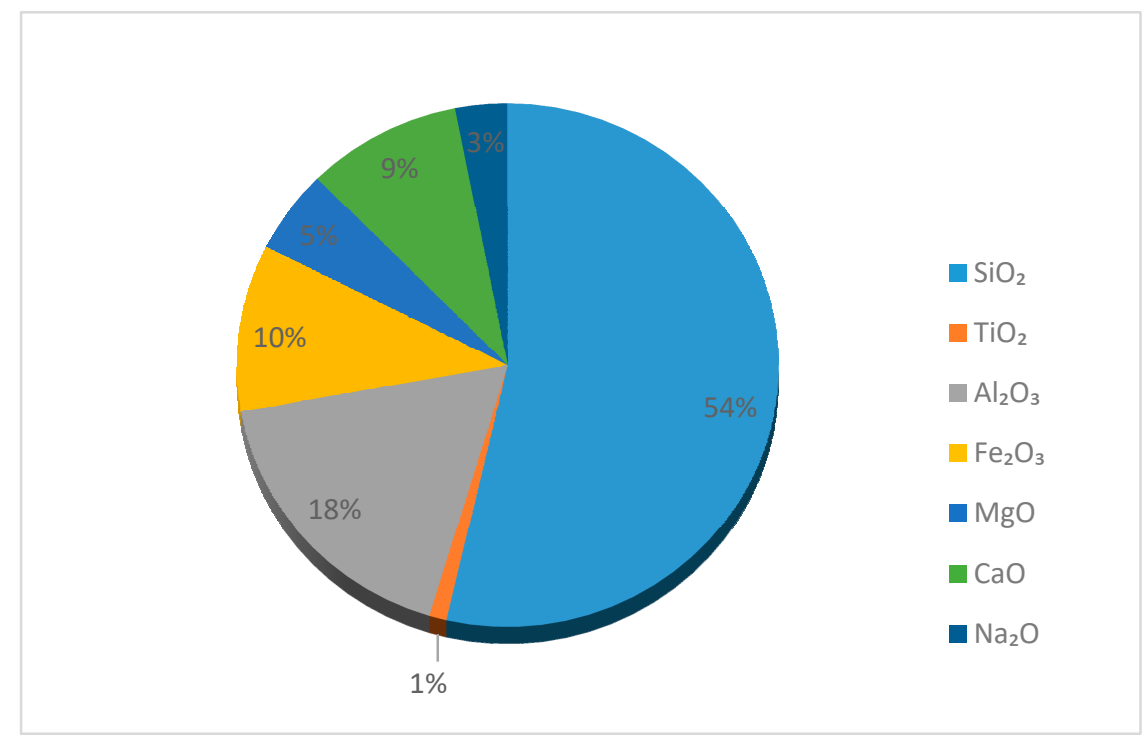

Figure 1. Chemical composition of basalt.

\subsubsection{Basalt Aggregate}

Basalt aggregate (Figure 2) is gained as a result of detachment of a piece of rock wall because of detonation of a bursting charge. Initially selected volcanic stone undergoes the process of grinding, until the desired effect is reached. Basalt aggregate has perfect characteristics: resistance to impact, compression, water, temperature fluctuations, frost and grinding. Basalt aggregate with graining 2-4 mm was used in the study. 


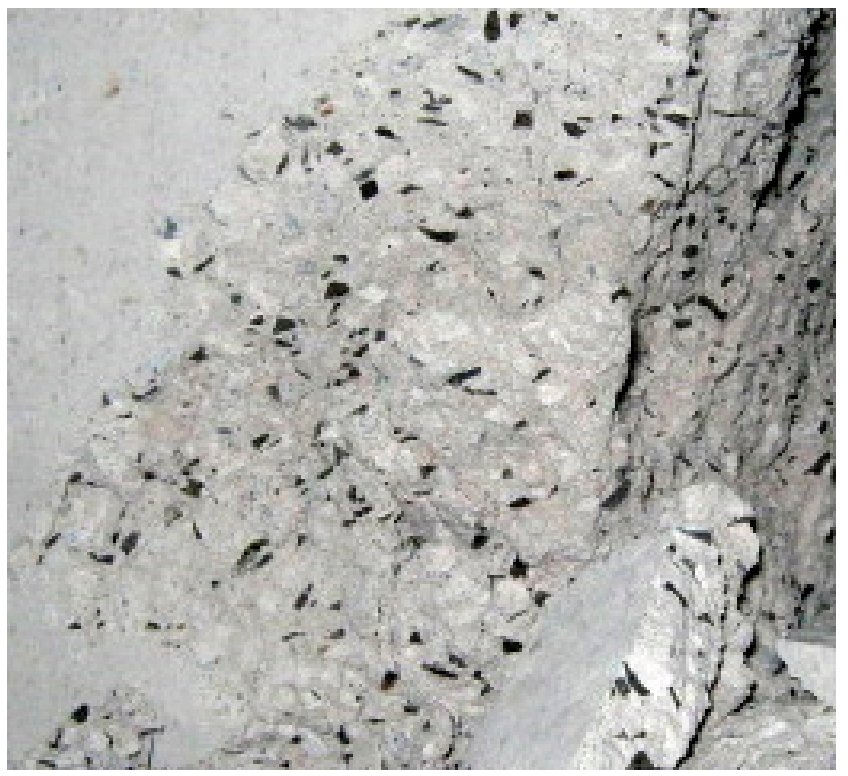

Figure 2. Basalt aggregate in sand-lime brick.

The main component of basalt aggregate and basalt components made of it is quartz, which can be separated into high- and low-temperature quartz. Thermodynamic changes occur mainly under pressure ( 1 bar is assumed) and temperature, the range of which varies depending on the material and needs. In the case of quartz, the so-called threshold temperature is $573^{\circ} \mathrm{C}$, where the change from alpha-quartz to beta-quartz occurs very rapidly and reversibly.

The chemical composition and form of basalt components have a significant impact not only on the physical and mechanical properties of modified building materials, but especially on the formation and synthesis of phases (C-S-H, tobermorite, huntite, etc.). For example, Al stabilizes the synthesis of tobermorite [20], $\mathrm{MgO}$ may affect the swelling of the material, and too high concentration of $\mathrm{CO}_{2}$ during the production of material affects the so-called acidification of the product (concrete, bricks), which in turn leads to faster destruction of construction materials. Due to climatic changes (large and rapid temperature changes, floods, heat, melting of oceans, sudden weather phenomena), high concentration of $\mathrm{CO}_{2}$ in the atmosphere, progressive technological and industrial development, research is being conducted to try to inhibit or neutralize progressing changes [21].

The reactivity of minerals and additives to concretes or bricks (including sand-lime bricks) increases with their fragmentation and the content of amorphous phases increasing (therefore the excellent addition to concrete is fly ash). Additives with a crystalline structure show less reactivity than amorphous additives, however, they are more resistant to thermodynamic changes. Thermodynamic bases are mainly carried out for concretes and their modifications, whereas they are missing for materials generated as a result of hydrothermal treatment (autoclaved concretes, sand-lime bricks). Therefore, it is difficult to estimate and compare the durability and effectiveness of the conducted research. However, the presented modifications are necessary to create an algorithm of changes that may occur over time. Below in the table (Table 1) is presented the conditions of thermodynamic system equilibrium for components of basalt aggregate, because the composition, properties and reactivity of minerals forming the addition to the silicate mass depend on its physical and mechanical properties and durability. 
Table 1. The conditions of thermodynamic system equilibrium for components of basalt aggregate [22].

\begin{tabular}{|c|c|c|c|c|c|c|c|}
\hline Phase & $\begin{array}{l}\log _{10} K \\
\left(25^{\circ} \mathrm{C}\right)\end{array}$ & $\begin{array}{c}\Delta_{\mathrm{f}} \mathrm{G} \\
(\mathrm{kJ} / \mathrm{mol})\end{array}$ & $\begin{array}{c}\Delta_{\mathrm{f}} \mathrm{H} \\
(\mathrm{kJ} / \mathrm{mol})\end{array}$ & $\begin{array}{c}S \\
(\mathrm{~J} / \mathrm{mol} \cdot \mathrm{K})\end{array}$ & $\underset{(\mathrm{J} / \mathrm{mol} \cdot \mathrm{K})}{\mathrm{C}_{\mathrm{p}}}$ & $\begin{array}{c}\mathrm{V} \\
\left(\mathrm{cm}^{3} / \mathrm{mol}\right)\end{array}$ & $\begin{array}{c}\mathrm{M} \\
\left(\mathrm{g} \cdot \mathrm{mol}^{-1}\right)\end{array}$ \\
\hline$\alpha-\mathrm{SiO}_{2}$ & -3.74 & -85681 & -910700 & 41.439 & 44.59 & 22.690 & 60.084 \\
\hline$\beta-\mathrm{SiO}_{2}$ & -3.51 & -854955 & -908670 & 43.799 & 44.75 & - & 60.084 \\
\hline $\begin{array}{l}\text { Hematite } \\
\mathrm{Fe}_{2} \mathrm{O}_{3}\end{array}$ & -0.04 & -744249 & -826230 & 87.404 & 103.88 & 30.300 & 159.692 \\
\hline $\begin{array}{c}\text { Magnetite } \\
\mathrm{Fe}_{3} \mathrm{O}_{4}\end{array}$ & 10.36 & -1012529 & -1115726 & 146.140 & 150.92 & 44.524 & 231.539 \\
\hline
\end{tabular}

The quality, durability and strength properties of building materials are mainly influenced by thermodynamic changes of minerals included in the modifiers (here basalt) in time and under the influence of temperature (data for: $\left.298.15 \mathrm{~K}\left(25^{\circ} \mathrm{C}\right), 1 \mathrm{bar}, \log _{10} \mathrm{~K}\right)$ (Table 2$)$.

Table 2. Autoprotolysis of water, the ability of water to dissolve the substance under the influence of external factors (here temperature).

\begin{tabular}{ccccccccc}
\hline $\begin{array}{c}\mathbf{T}\left({ }^{\circ} \mathbf{C}\right) \\
\log _{\mathbf{1 0}} \mathbf{K}\end{array}$ & $\mathbf{0}$ & $\mathbf{2 5}$ & $\mathbf{6 0}$ & $\mathbf{1 0 0}$ & $\mathbf{1 5 0}$ & $\mathbf{2 0 0}$ & $\mathbf{2 5 0}$ & $\mathbf{3 0 0}$ \\
\hline$\alpha$-quartz & -4.08 & -3.74 & -3.35 & -2.98 & -2.62 & -2.34 & -2.11 & -1.93 \\
$\beta$-quartz & -3.81 & -3.51 & -3.15 & -2.82 & -2.50 & -2.24 & -2.04 & -1.87 \\
Hematite & 2.02 & -0.04 & -2.42 & -4.61 & -6.82 & -8.69 & -10.40 & -12.09 \\
Magnetite & 13.81 & 10.36 & 6.39 & 2.76 & -0.88 & -3.92 & -6.62 & -9.22 \\
\hline
\end{tabular}

\subsubsection{Basalt Powder}

Basalt powder (Figure 3) is gained in the process of breaking of basalt aggregate and through your fragmentation can be more reactive. Substantial amounts of fine-grained fractions are useless for the main market recipients (road and railway construction, concrete production), whereas for mines it is problematic concerning its transport and storage. Some years ago, basalt powder was treated as useless waste. However, for a few years now, even the smallest amounts of basalt graining fractions are used as e.g., coverage for newly laid bitumen layers, remineralizing material in farming or in ceramic industry as full-value ingredient of fiber composition of clinker production using the method of pressing [23]. Basalt powder with graining of up to $0.08 \mathrm{~mm}$ was used in the study.

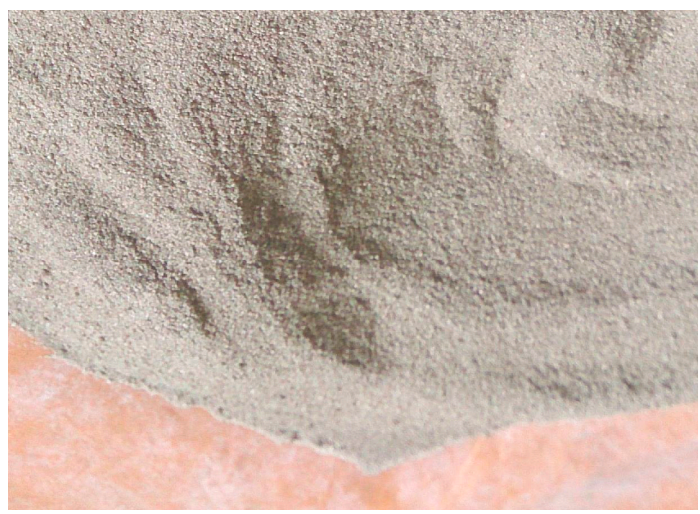

Figure 3. Basalt powder.

\subsubsection{Basalt Fiber}

Basalt fiber (Figure 4) is gained as a result of melting process of aggregate of basalt stone in the temperature exceeding $1450{ }^{\circ} \mathrm{C}$. Liquid basalt mass is then pressed by platinum sleeves. Received this way, endless monofilaments are covered with proper silan sizing and are merged with basalt 
monofilament bunches, the so-called rovings. The silan sizing has the protective function of the fiber, it increases its elasticity and also improves its connection with composite matrix. The most important features of basalt fibers are: high tensile strength, high elasticity module, resistance to high temperatures, being environmentally friendly and easiness of disposal [24]. Fibers with monofilament diameter of $13 \mathrm{~nm}$ and length of $1.5 \mathrm{~mm}$ were used in the study.

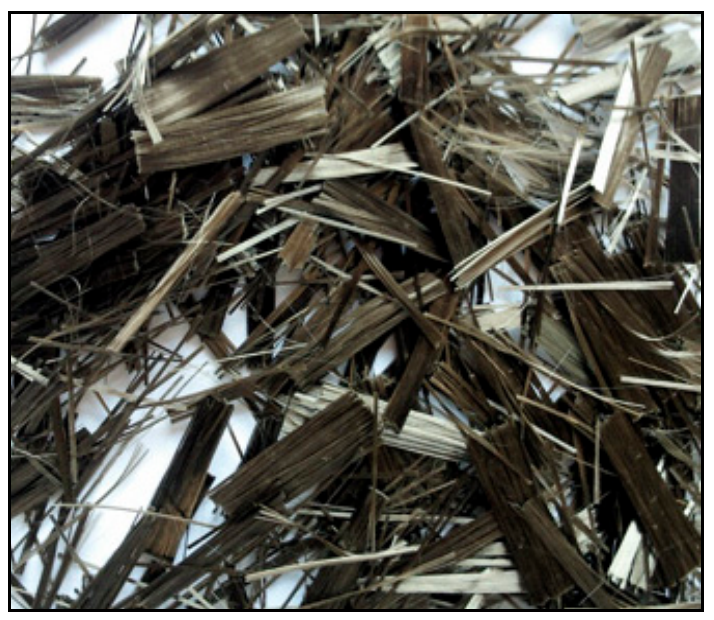

Figure 4. Basalt fiber.

\subsection{Preparation of Samples}

The procedure of preparation of particular mixtures and formation of samples proceeded in arranged and repetitive manner. Modifier, which already included sand, quicklime and water was introduced into the raw mixture, after the process of lime slaking. The sample labeled with " $\mathrm{T}^{\text {" symbol }}$ refers to the traditional product, where as "BA" it is the basalt aggregate, "BP" it is basalt powder, "BF" it is basalt fiber (Table 3).

Table 3. Percentage of ingredients of sand-lime products.

\begin{tabular}{ccc}
\hline Symbol of the Sample & Sand-Lime Mass (\%) & Addition (BA/BP/BF) (\%) \\
\hline N & 100 & 0 \\
BA & $50-70$ & $10-50$ \\
BP & $90-70$ & $10-30$ \\
BF & 100 & $0.3-1$ \\
\hline
\end{tabular}

After the process of homogenization of ingredients, the raw mass was placed in tines and pressed under the pressure of $20 \mathrm{MPa}$. Then, the samples matured in the autoclave for $8 \mathrm{~h}, 6$ of which in the temperature of $203^{\circ} \mathrm{C}$ (according to the rule $1 \mathrm{~h}$ heating $+6 \mathrm{~h}$ of the proper autoclaving $+1 \mathrm{~h}$ cooling), under the pressure of $1.6 \mathrm{MPa}$. The research was performed after 21 days since the samples were stored in dry-air conditions and re-formed.

\subsection{Performed Research}

The study of physical features of the received materials was performed according to the range and methods specified in the norms concerning particular qualities: water absorbability, volume and compressive strength [25-29]. An extremely important aspect is the contact zone cement/aggregate, binder/aggregate [30]. The first examination that was performed, concerned compressive resistance. The tests were performed using the Tecnotest KC300 press (Modena Italy). Absorbability is the mass of water which can be absorbed by a sample, completely immersed in water, at atmospheric pressure. Typically, absorbability of building materials depends on the porosity. This is due to the fact that water cannot get into the closed pores, while in the case of large pores-it only moistens their walls. 
The process of water absorption through capillary rising by the sample consisted in elements in water at a given depth (in $\mathrm{mm}$ ) and for a given time. The test was conducted in accordance with the standard. The samples were dried at $70{ }^{\circ} \mathrm{C}$ to constant weight. Then, after cooling the samples, they were immersed in water for a limited time. After the lapsed time has elapsed, the percentage difference in weight of the dry sample and after soaking was calculated, this result is absorbability.

The mixture of material gained in hydrothermal conditions was examined using the method of microscope scanning. In the examination, scanning electrone microscope SEM type Quanta ${ }^{\text {TM }}$ FEG 250 FEI Company with the EDS analyzer (FEI/01/12/2019) was used. The phase composition of samples was determined using the XRD (X-ray diffractometer) PANalytical Empyrean. Participation of particular phases was estimated via Rietveld method. The measurements were performed using monochromatic radiation with the wave length corresponding with the K-alpha emission line of copper, angle range $5-90^{\circ}$ in the scale of 20.

\section{Results}

The results of the research of physico-mechanical features of sand-lime products with addition of basalt components and reference samples are placed in Table 4, Figures 5 and 6.

Table 4. Physico-mechanical features of sand-lime products.

\begin{tabular}{cccc}
\hline Name of the Sample & $\begin{array}{c}\text { Compressive Strength } \\
\mathbf{N} / \mathbf{m m}^{\mathbf{2}}\end{array}$ & $\begin{array}{c}\text { Bulk Density } \\
\mathbf{( k g / \mathbf { m } ^ { 3 } )}\end{array}$ & $\begin{array}{c}\text { Absorbability } \\
\mathbf{( \% )}\end{array}$ \\
\hline N & 12.040 & 1600 & 16.0 \\
BA-10 & 37.100 & 2000 & 14.7 \\
BA-20 & 36.700 & 2050 & 13.5 \\
BA-30 & 34.500 & 2160 & 12.0 \\
BA-40 & 33.500 & 2220 & 9.5 \\
BA-50 & 29.700 & 2229 & 9.0 \\
BP-10 & 27.560 & 1700 & 18.0 \\
BP-20 & 15.040 & 1730 & 20.2 \\
BP-30 & 10.720 & 1750 & 21.9 \\
BF-0,3 & 8.400 & 1680 & 16.1 \\
BF-0,6 & 6.040 & 1635 & 16.3 \\
BF-1 & 5.500 & 1620 & 16.6 \\
\hline
\end{tabular}

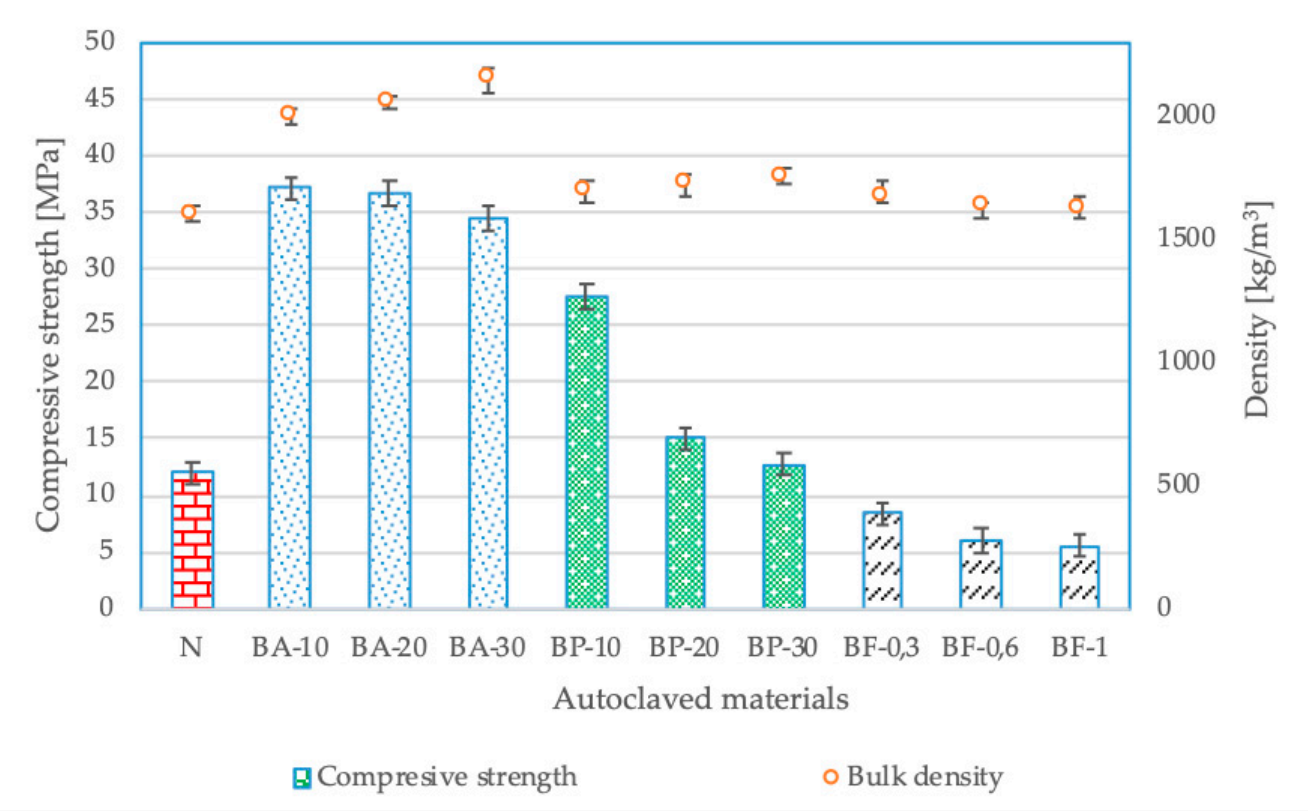

Figure 5. Compressive strength and bulk density compilation of different sand-lime products. 


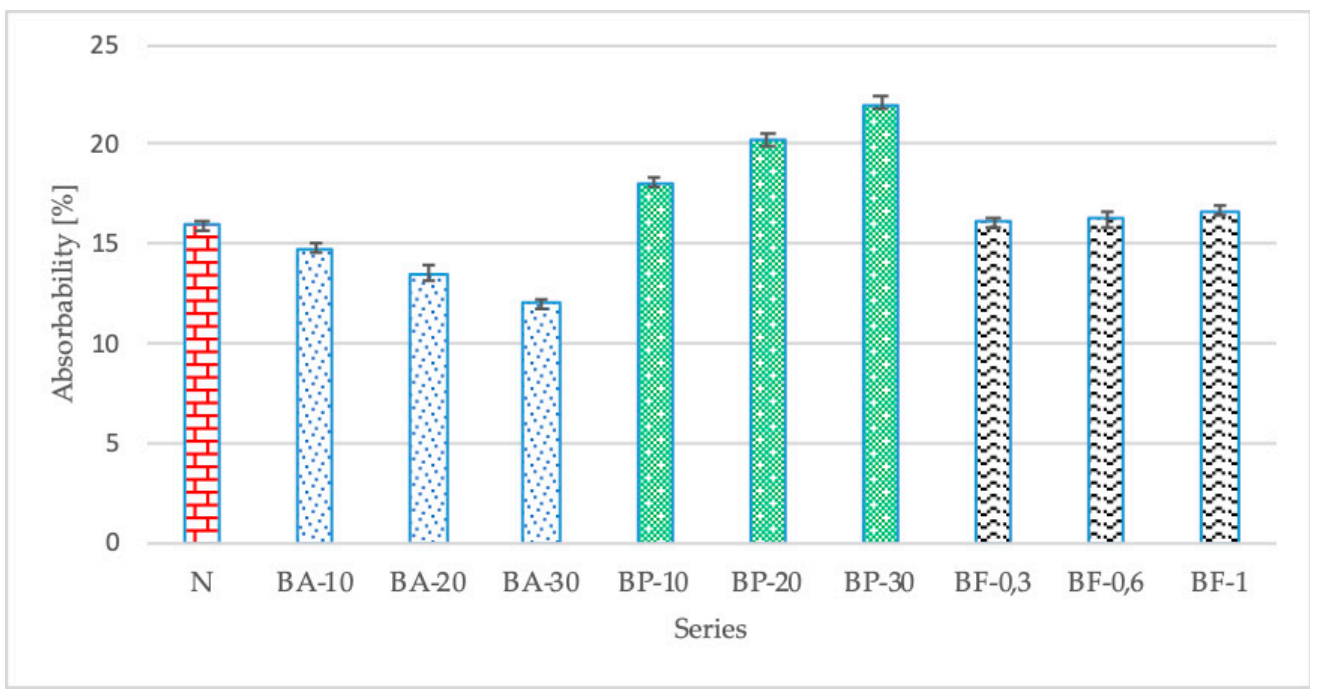

Figure 6. Absorbability test of the different sand-lime products.

The amount and kind of phases of hydrated lime silica created in the process of autoclaving influences the compressive resistance and other qualities of sand-lime products.

The presented results are averaged values (Figures 5 and 6). Each average result includes error bars, but in some cases they were small enough to be invisible on the graph. The tests were carried out for 12 different series (N; BA-10; BA-20; BA-30; BA-40; BA-50; BP-10; BP-20; BP-30; BF-0.3; BF-0.6; BF-0.9), each of which had a different composition. After the preliminary tests, it was decided to narrow down the research area to 10 product series: N; BA-10; BA-20; BA-30; BP-10; BP-20; BP-30; BF-0.3; BF-0.6; BF-0.9. Each series consisted of 6 samples that were tested.

\section{Microstructure and Structure Sand-Lime Bricks Modified by Basalts Compounds}

Photographs below present the microstructure of samples of sand-lime products, the reference sample (Figure 7a,b) and the samples modified with basalt components (Figure 8a,b-sample with BA, Figure $9 a, b$-sample with BP, Figure 10a,b-sample with BF). Traditional sand-lime products show presence hydrated lime silica with tobermorite structure and C-S-H phase (Tables 5 and 6). Creation and frequency of occurrence of particular structures is connected with the quality of the components used and their chemical reactivity. Basalt aggregate was used as addition, which triggered changes in the placement and dimensions of the free area in the examined material.

$$
\mathrm{CaO}+\mathrm{H}_{2} \mathrm{O}+\mathrm{SiO}_{2}=>\text { C-S-H }
$$

(C-S-H or other phases such as tobermorite, jennite, awfilite, which depends on hydrothermal conditions)

$$
\mathrm{Ca}(\mathrm{OH})_{2}+\mathrm{CO}_{2}=>\mathrm{CaCO}_{3}+\mathrm{H}_{2} \mathrm{O}
$$

Due to the low lime content and the high temperature of brick production, the main phase is tobermorite, not C-S-H phase as in the case of concretes materials.

During the modification of the sand-lime mass with basaltic components, in the hydrothermal conditions tobermorite was formed, which is characterized by a smaller surface area relative to the amorphous C-S-H phase and higher thermodynamic stability as indicated in the above tables.

However, it did not affect the frequency of occurrence of particular phases. C/S ratio research should be performed in order to analyze the matter thoroughly. 


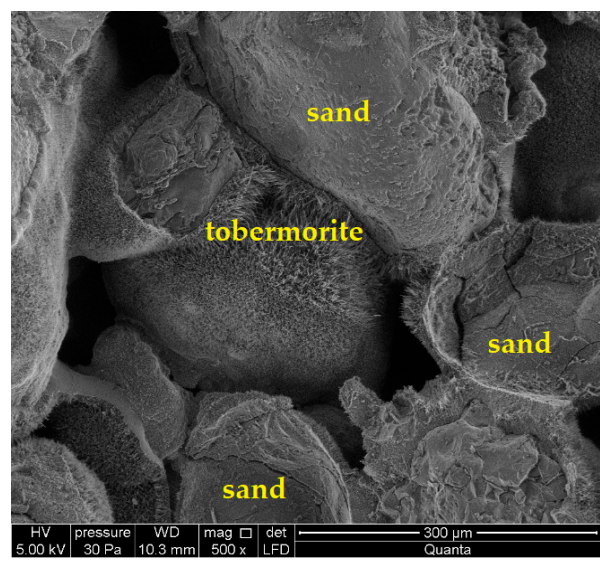

(a)

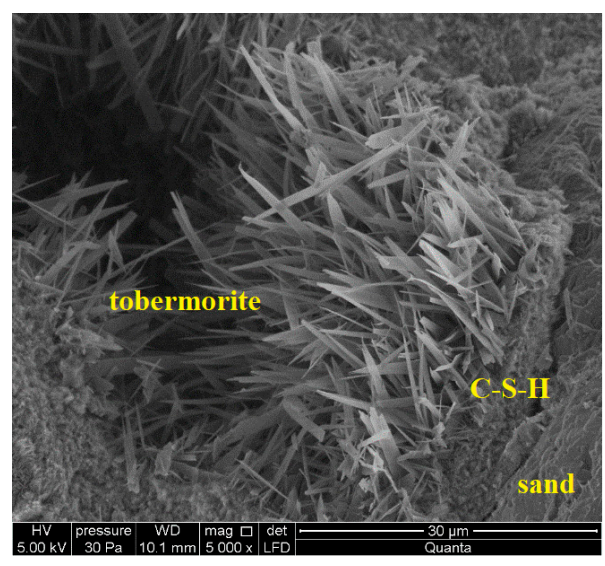

(b)

Figure 7. Microstructure of traditional samples. (a) SEM picture: 500x magnification; (b) SEM picture: $5000 \times$ magnification.

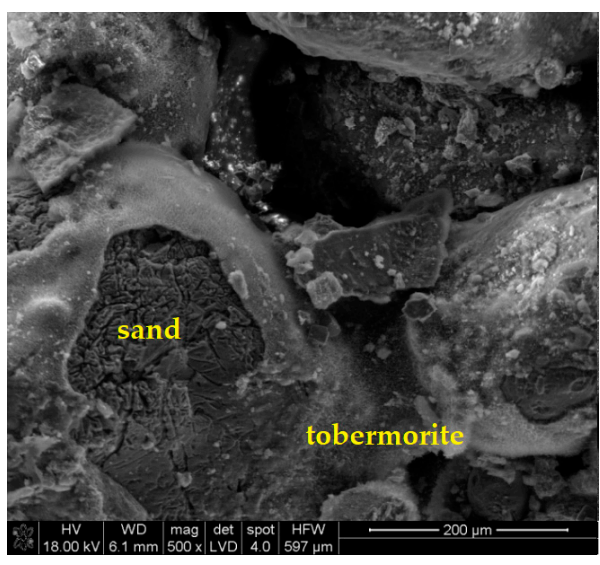

(a)

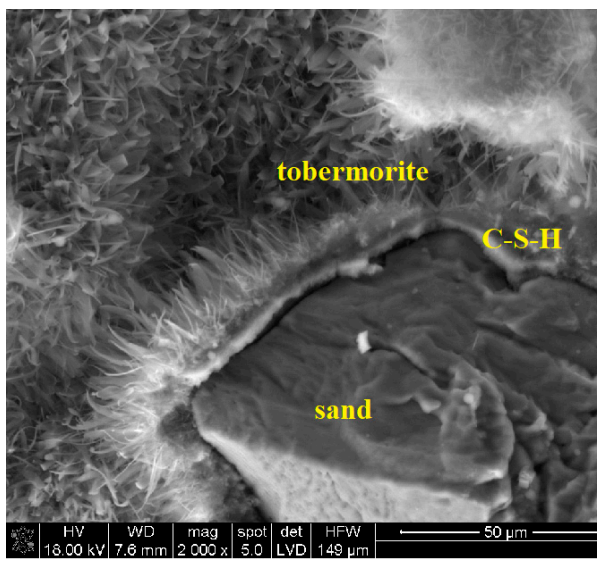

(b)

Figure 8. Microstructure of samples modified with basalt aggregate (BA). (a) SEM picture: 500x magnification; (b) SEM picture: 2000x magnification.

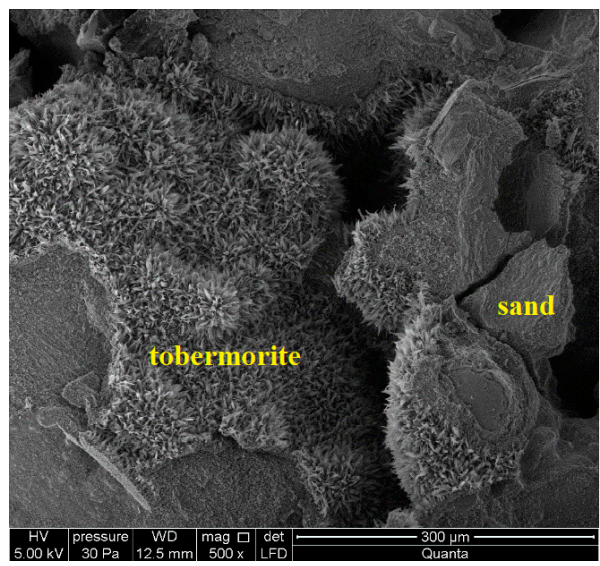

(a)

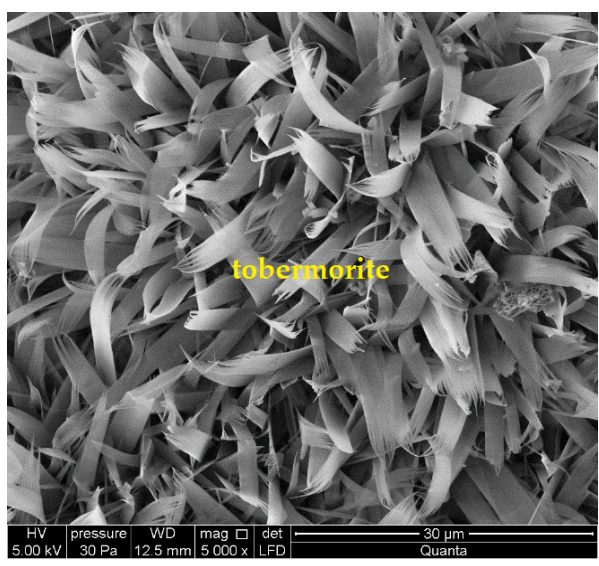

(b)

Figure 9. Microstructure of samples modified with basalt powder (BP). (a) SEM picture: 500x magnification; (b) SEM picture: 5000x magnification. 


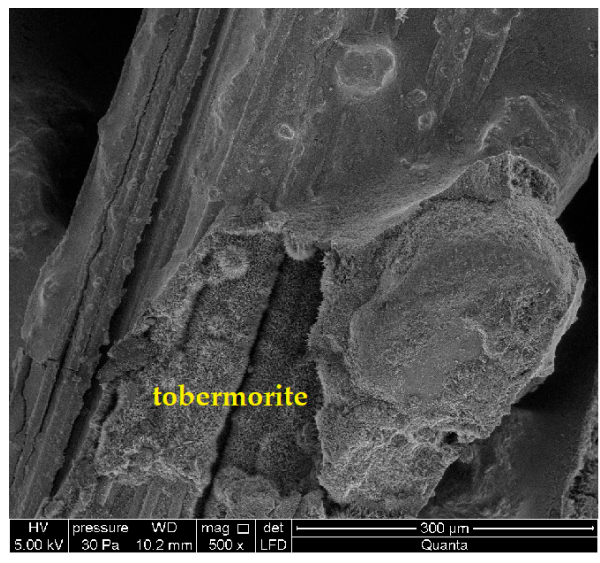

(a)

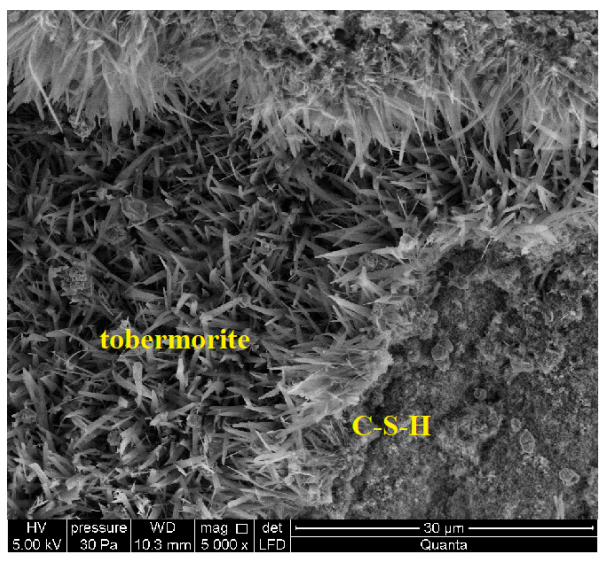

(b)

Figure 10. Microstructure of samples modified with basalt fibre (BF). (a) SEM picture: 500x magnification; (b) SEM picture: 5000x magnification.

Table 5. The main phases of the microstructure of the sand-lime bricks.

\begin{tabular}{|c|c|c|c|c|c|c|c|}
\hline Phase & $\begin{array}{l}\log _{10} \mathrm{~K} \\
\left(25^{\circ} \mathrm{C}\right)\end{array}$ & $\begin{array}{c}\Delta_{\mathrm{f}} \mathrm{G} \\
(\mathrm{kJ} / \mathrm{mol})\end{array}$ & $\begin{array}{c}\Delta_{\mathrm{f}} \mathrm{H} \\
(\mathrm{kJ} / \mathrm{mol})\end{array}$ & $\begin{array}{c}\mathrm{S} \\
(\mathrm{J} / \mathrm{mol} \cdot \mathrm{K})\end{array}$ & $\underset{(\mathrm{J} / \mathrm{mol} \cdot \mathrm{K})}{\mathrm{C}_{\mathrm{p}}}$ & $\begin{array}{c}\mathrm{V} \\
\left(\mathrm{cm}^{3} / \mathrm{mol}\right)\end{array}$ & $\begin{array}{c}\mathrm{M} \\
\left(\mathrm{g} \cdot \mathrm{mol}^{-1}\right)\end{array}$ \\
\hline $\begin{array}{c}\text { Tobermorite } \\
\mathrm{Ca}_{5} \mathrm{Si}_{6} \mathrm{H}_{11} \mathrm{O}_{22 \cdot 5}\end{array}$ & 65.58 & -989345 & -10680920 & 692.553 & 764.91 & 286.190 & 739.977 \\
\hline $\begin{array}{c}\text { C-S-H } \\
\mathrm{Ca}_{0.8} \mathrm{SiO}_{2 \cdot 8}: 1.54 \mathrm{H}_{2} \mathrm{O}\end{array}$ & 11.05 & -1769025 & -1945130 & 107.850 & 138.38 & 59.290 & 132.690 \\
\hline
\end{tabular}

Table 6. Autoprotolysis of water, the ability of water to dissolve the substance under the influence of external factors (basic temperature $25^{\circ} \mathrm{C}$ and higher) [30].

\begin{tabular}{ccc}
\hline $\mathbf{T}\left({ }^{\circ} \mathbf{C}\right) \log _{\mathbf{1 0}} \mathbf{K}$ & Tobermorite & C-S-H phase \\
\hline 0 & 71.6 & 11.38 \\
$\mathbf{2 5}$ & $\mathbf{6 5 . 5 8}$ & $\mathbf{1 1 . 0 5}$ \\
60 & 58.8 & 10.2 \\
100 & 52.74 & 9.46 \\
150 & 46.88 & 8.78 \\
200 & 42.27 & 8.27 \\
250 & 38.4 & 7.85 \\
300 & 34.91 & 7.48 \\
\hline
\end{tabular}

The modification did not affect the formation of other phases than tobermorite, which is present in traditional sand-lime products (low lime content and high temperature $\left(200{ }^{\circ} \mathrm{C}\right)$ ) tend to material the crystallization of the sample towards the tobermorite, not for example jennite). Therefore, the thermodynamic properties of the minerals present in the bases are taken into account in order to be aware of the addition of the degree of reactivity which we had during the modification of the sand-lime mass. Basalt aggregates are less reactive due to their crystalline and microcrystalline structure. A similar situation is with basalt powder.

Basalt fibers are resistant to high temperatures. They do not melt at $200{ }^{\circ} \mathrm{C}$. The lime-sand mixture clings to them and crystalline phases form at the interface of materials.

The results of the phase composition (XRD structure: X-ray Powder Ddiffraction [keV]) with the qualitative analysis of the samples are presented in Figure 11 (traditional sample), Figure 12 (with BA) and Figure 13 (with BP). 


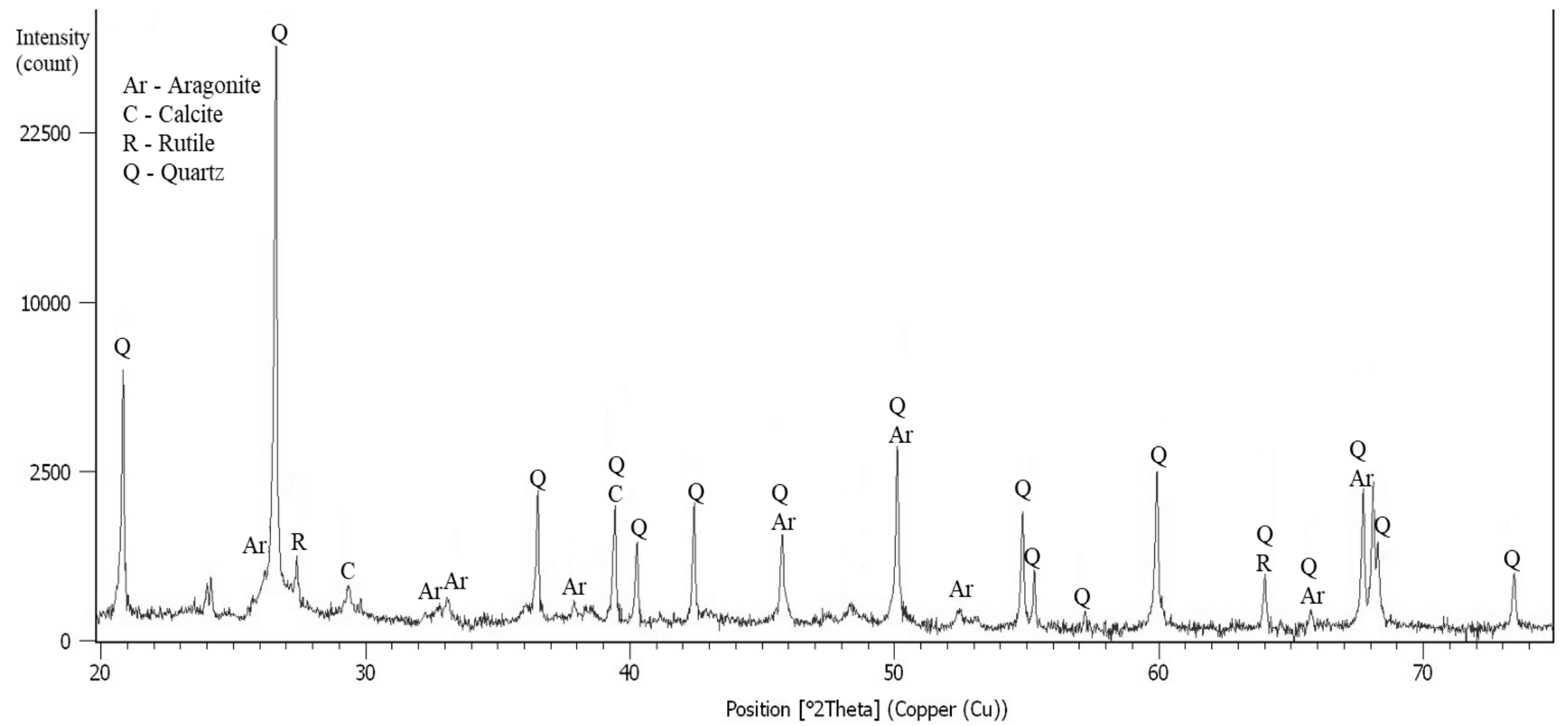

Figure 11. XRD (X-ray Powder Ddiffraction) for traditional sample [keV]. 


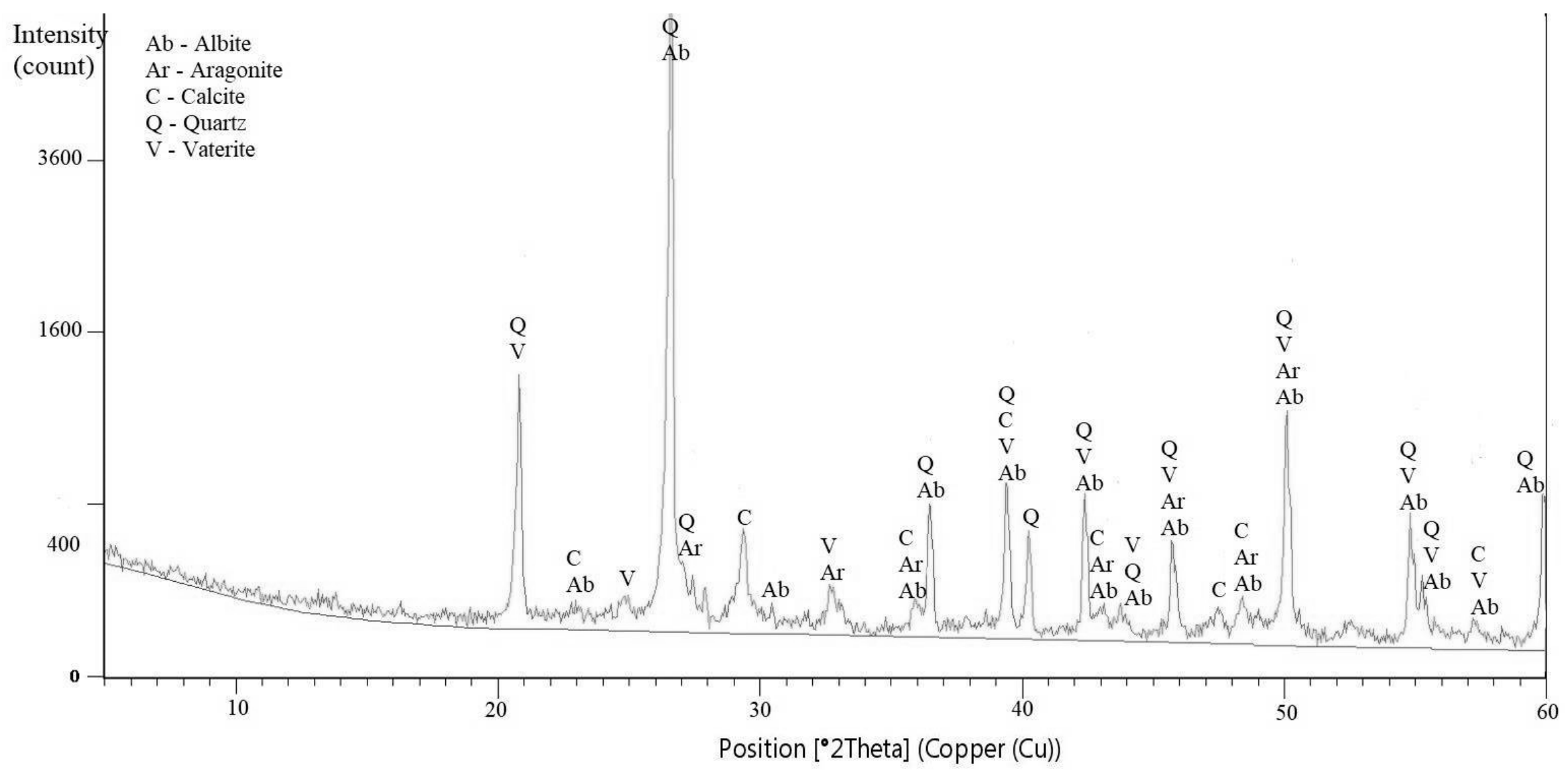

Figure 12. XRD sample with basalt aggregate [keV]. 


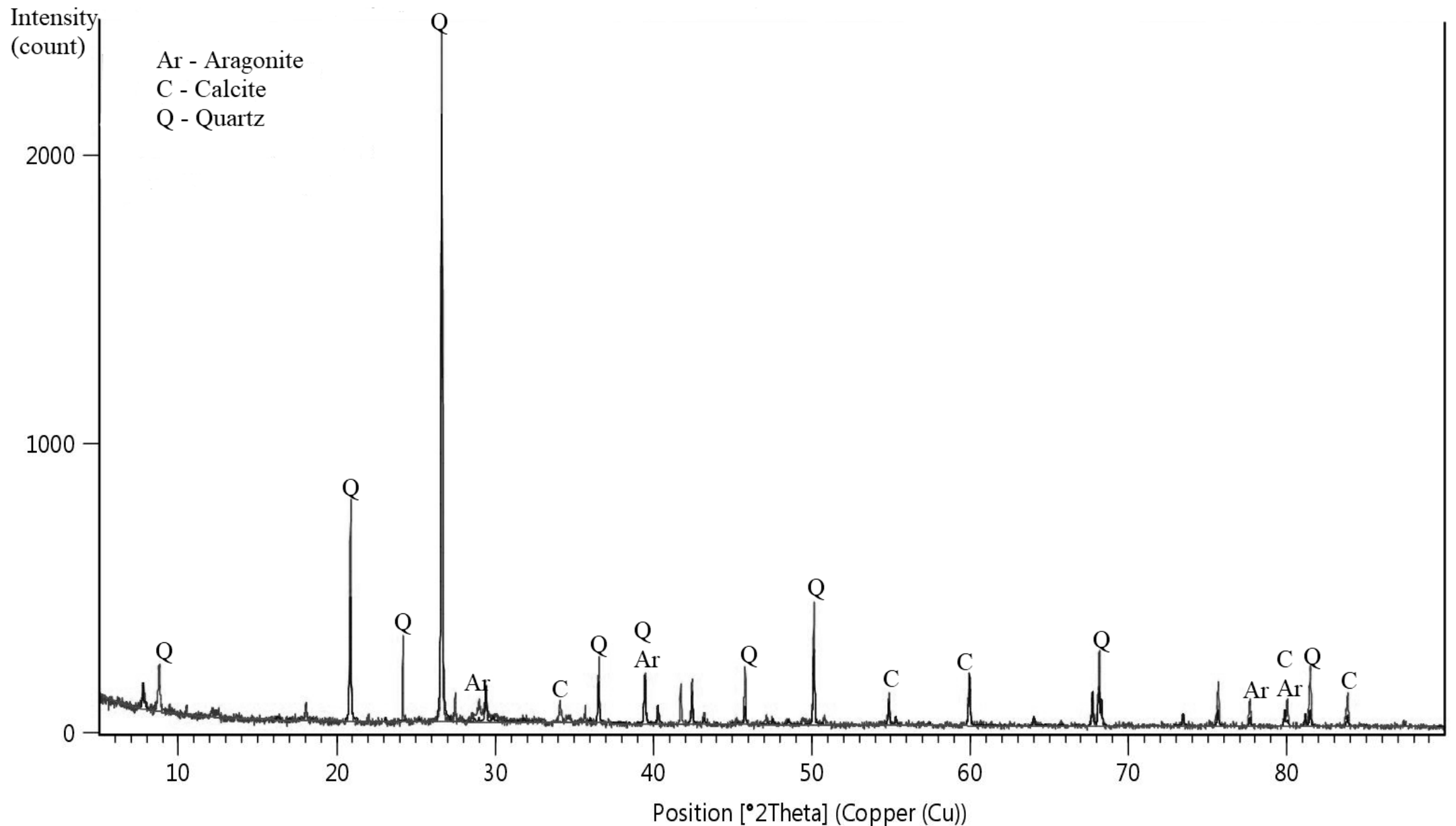

Figure 13. XRD sample with basalt powder [keV]. 
In the diffractograms of the samples there is an increased background in the range and reflections which indicates the presence of crystalline phases in these samples. In the Reference sample together with the amorphous phase following crystalline phases such as: $\alpha$-quartz monoclinic $\mathrm{SiO}_{2}$ and tobermorite. Studies show similarities, because additives with a crystalline structure were used for modification, but in a different form.

\section{Discussion}

Comparing the results of the research on traditional materials and those modified with basalt components, significant changes of basic physic-mechanical parameters are visible, essential in the case of compressive resistance and volume density. The difference in water absorbability in sample modified with basalt aggregate compared with the reference sample, reaches up to $50 \%$. The product modified with basalt aggregate shows decrease in water absorption as a result of capillary action and in absorbability up to $9 \%$ (in the reference sample up to $16 \%$ ). The sample with the addition of basalt aggregate shows compressive resistance of $33 \mathrm{MPa}$ on average, with the increase of volume density to $2.29 \mathrm{~kg} / \mathrm{dm}^{3}$. In the single-family constructions, such a level of compressive resistance is not required, however the situation varies in the case of multi-family constructions and public buildings.

Modification of sand-lime mixture with basalt powder presented satisfying results with its little use, beneficially on about 10 weight per cent. In more than 20 weight per cent, there was a decrease of resistance, which may be connected with too big amount of little fractions in the mixture and the lack of suitable amount of lime, essential for the reaction. Along with the increase of the amount of basalt powder, volume density and absorbability of the product increased. Higher volume density is caused by dense insertion of the components, because of the use of little powder, which fulfills the empty spaces. As a result, bigger amounts of pores with little diameters-capillary pores.

Application of basalt fibers slightly changed the volume density and absorbability compared with the norm sample. However, it affected the compressive resistance. As a result of hydrothermal processing of sand-lime products, hydrated lime silicates are formed, varying in the level of structure ordering from the amorphous to crystalline phase. Chemical reactions of that process depend on the following parameters: temperature, pressure, reagent concentration, presence of catalyzers, speed of embryos formation, speed of embryos growth. In the $\mathrm{CaO}-\mathrm{SiO}_{2}-\mathrm{H}_{2} \mathrm{O}$ system, during the process of autoclaving, compounds that do not occur in normal temperatures are created. Between the temperature of $20^{\circ} \mathrm{C}$ and $190^{\circ} \mathrm{C}$, the speed of reaction of creating those compounds increases for over million times [31].

In the hydrothermal conditions, solubility of silica increases, whereas that of calcium hydroxide decreases [32].

During the process of autoclaving it is impossible to gain the effect of over-reaction of sand and lime. Solubility of quartz and the process of silica cations diffusion trigger the process of creation of new phases on the surface of sand grains. When those processes stop, the reactions of creation of hydrated lime silica in hydrothermal conditions nearly balance [31].

Compared to the microstructure of the traditional product with modified basalt components, some changes are visible. All phases include C-S-H phase and tobermorite. The samples with basalt aggregate and basalt powder, the tobermorite takes the form of twisted sheets with frayed ends. In the standard sample, tobermotite has the form of well-educated needles.

In modified products-so-called "packaging of substrates" used in the manufacture of this product. Components introduced are aggregates in the form of aggregates, which are based on changes in the physico-mechanical properties of the material. The quantity of lime to be dosed and the production process is not irrelevant, although this process does not change.

$\mathrm{X}$-ray phase analysis allows us to recognize and distinguish crystalline materials that have different structures, but the same chemical composition (polymorphic variants), allows us to examine the phase composition of materials that are a mixture of many different phases or to recognize in a very simple way, In general, we have a crystalline or amorphous phase [33]. XRD analysis of traditional sand-lime 
sample, as in the case of samples with added basalt components, showed the presence of quartz, calcite and tobermorite or other calcium silicate. In the sample with basalt powder additionally detected clinotobermorite. The structure of the materials also determines their durability. The process of carbonation in construction materials is associated with the possibility of $\mathrm{CO}_{2}$ penetration into the concrete structure. Safety and ecology and the intensity of this process are related to the tightness of the concrete structure, which depends on: the $\mathrm{W} / \mathrm{C}$ ratio and the conditions of making the concrete. Alex Reggiani explains that carbonates tend to react with the aluminate fraction, leading to the formation of carboaluminates (which is present in cement paste and in turn shifts the equilibrium reducing the precipitation of monosulfate in favour of ettringite). There's quite a consolidated literature on the thermodynamics aspect of these reactions, see e.g., the work of Lothenbach B. and Matschei T. The priority topic may be the effect of $\mathrm{CaCO}_{3}$ on calcium hydrated silicates and the GEMS program (Cemdata) can be used to simulate of this proces, but it is used mainly for concrete and up to $100{ }^{\circ} \mathrm{C}$ [34-37]. All these reactions depend on thermodynamic changes taking place in the minerals that form the basis of the cement and then on the concrete. An important aspect is the concentration of $\mathrm{CO}_{2}$ in the atmosphere and the amount of C-S-H in the concrete (usually it's 60-70\%). The C-S-H phase is thermodynamically stable at $25-30{ }^{\circ} \mathrm{C}$, but crystallizes at higher temperatures. In our bricks, the C-S-H phase is in the minimum amount, because in the hydrothermal conditions and at low content of $\mathrm{CaO}$ tobermorite crystallizes. The bricks are dominated by crystalline phases. During the modification of bricks we use sand-lime mix.

\section{Conclusions}

Present studies show the effect of addition of basalt components on individual properties of sand-lime products. Based on the research conducted, the following conclusions were made:

1. Addition of basalt aggregate and basalt powder increases the compressive strength of the products. The best results are achieved with the addition of $10 \%$ of these components. Basalt fibers have not improved strength compared to traditional samples.

2. With the increase in the proportion of basalt aggregate and basalt powder, the bulk density of sand-lime products increases. Because of low mass content, basalt fibers do not significantly affect volumetric density changes.

3. The absorbability of modified products drops even to $9 \%$ relative to the reference sample of $16 \%$.

4. The number of micropores increases and the number of macropores decreases, which translates into changes in physical and mechanical properties of the material, as well as microstructures e.g.,: the concentration of the phases.

Due to the improvement of the parameters of the products modified with the indicated components, the researches proved to be correct and beneficial. The research will continue with regard to the proportion of appropriate percentages of both the basalt aggregate and the basalt meal in order to obtain a more favorable bulk density of the grains. After the period of operation of the exemplary material it will be able to be reused, for example, in the form of aggregate or as ground silica-basalt meal. The materials made are subject to further examination.

Author Contributions: Conceptualization, A.S. and P.K.; Methodology, A.S. and P.K.; Software, P.K.; Validation, A.S. and P.K.; Formal Analysis, A.S.; Investigation, A.S. and P.K.; Resources, A.S. and P.K.; Data Curation, A.S. and P.K.; Writing-Original Draft Preparation, A.S. and P.K.; Writing-Review \& Editing, A.S. and P.K.; Visualization, A.S. and P.K.; Supervision, A.S.; Project Administration, A.S.; Funding Acquisition, P.K.

Funding: This research was supported by the Innovation Incubator 2.0 witch is co-funded by The Ministry of Science and Higher Education under Smart Growth Operational Programme.

Acknowledgments: First author would like to thank Gaurav N. Sant and Magdalena Balonis from the University of California Los Angeles (UCLA, LA, USA) and Maciej Sitarz from AGH University Science and Technology (Cracow, Poland) for their scientific support. 
Conflicts of Interest: The authors declare no conflict of interest. The funders had no role in the design of the study; in the collection, analyses, or interpretation of data; in the writing of the manuscript, and in the decision to publish the results.

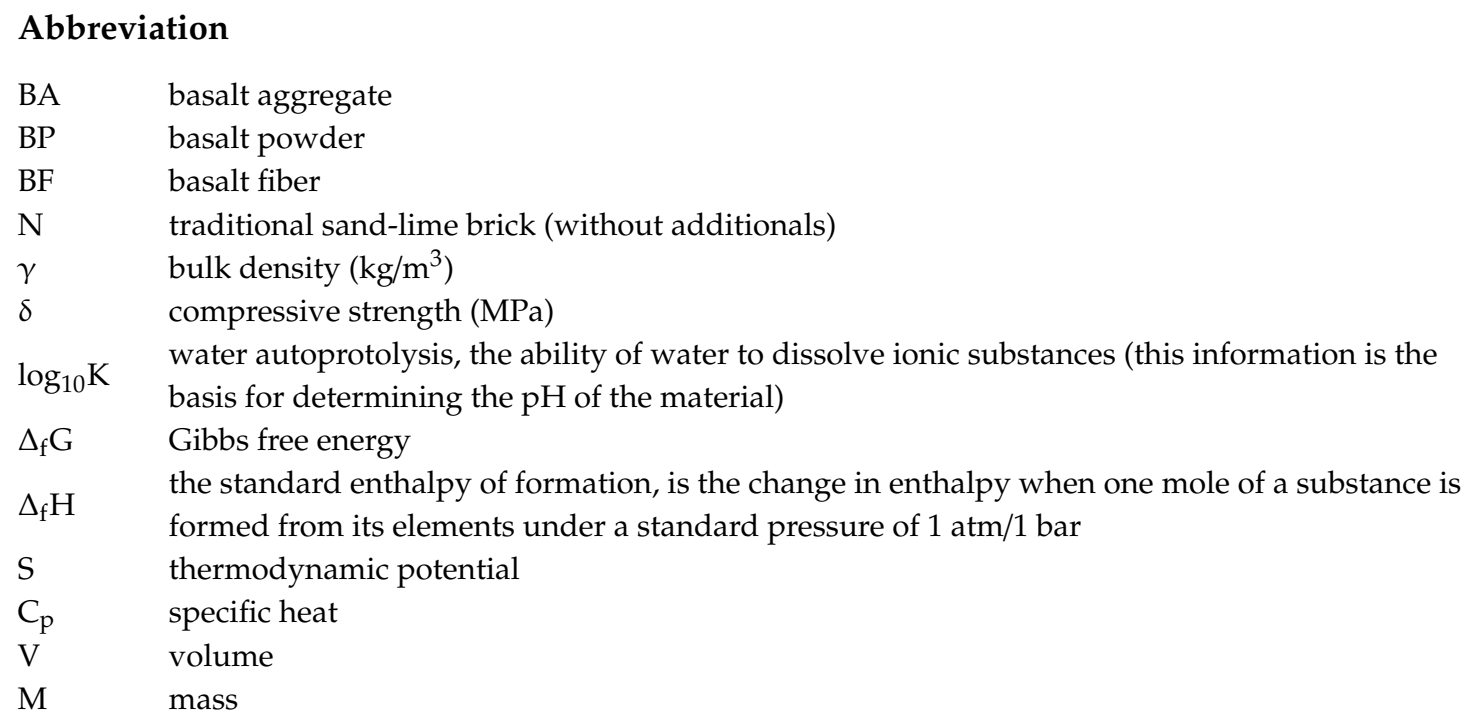

\section{References}

1. Pytel, Z. Modification of the phase composition and microstructure of autoclaved lime-sand materials. Ceramics 2014, 116, 162.

2. Polyzois, D.; Polyzoi, E.; Wells, J.; Koulis, T. Poor indoor air quality, mold exposure, and upper respiratory tract infections-Are we placing our children at risk? J. Environ. Health 2016, 78, 20-27. [PubMed]

3. Dachowski, R.; Kostrzewa, P. Mechanical properties, phase composition and microstructure of autoclaved sand-lime product. Int. Conf. Sustain. Energy Environ. Dev. 2019, 214, 1-8. [CrossRef]

4. Dachowski, R.; Kostrzewa, P.; Brelak, S. Autoclaved materials with chalcedonite addition. In 3rd Scientific Conference Environmental Challenges in Civil Engineering (Ecce 2018); Curran Associates, Inc.: New York, NY, USA, 2018; Volume 174.

5. Kostrzewa, P.; Dachowski, R. Impact of polyethylene glycol on porosity and microstructure of sand-lime product. In Proceedings of the 1st International Conference on the Sustainable Energy and Environment Development (Seed 2016), Krakow, Poland, 17-19 May 2016; Volume 10.

6. Kostrzewa, P.; Stepien, A. Autoclaved Sand-Lime Products with a Polypropylene Mesh. In Proceedings of the World Multidisciplinary Civil Engineering-Architecture-Urban Planning Symposium (Wmcaus 2017), Prague, Czech Republic, 12-16 June 2017; Volume 245.

7. Stepien, A. The impact of barium sulfate on the microstructural and mechanical properties of autoclaved silicate products. In Proceedings of the 9th International Conference Environmental Engineering (9th ICEE)-Selected Papers, Vilnius, Lithuania, 22-24 May 2014.

8. Dachowski, R.; Stępień, A. Mass of Silicate Products. Patent No. 396499, 2 October 2011.

9. Dachowski, R.; Steppień, A. Mass of Silicate Products with High Compressive Strength Features. Patent No. 396498, 2 October 2011.

10. Dachowski, R.; Kostrzewa, P. The use of waste materials in the construction industry. World Multidiscip. Civ. Eng. Archit. Urban Plan. Symp. WMCAUS 2016, 161, 754-758. [CrossRef]

11. Stepien, A. The impact of glass additives on the functional and microstructural properties of sand-lime bricks. In Proceedings of the 19th International Conference on Civil Engineering and Adapting Civil Engineering Practice, Rome, Italy, 5-6 March 2017.

12. Dachowski, R.; Stępień, A. Method and Research to Determine Acoustic Insulation of Building Elements and Calcium Silicate and Concrete Materials in Particular. Patent No. 205358, 25 March 2009.

13. Olenets, M.; Piotrowski, J.; Stroy, A. Heat transfer and air movement in the ventilated air gap of passive solar heating systems with regulation of the heat supply. Energy Build. 2015, 103, 198-205. [CrossRef] 
14. Piotrowski, J.; Stroy, A.; Olenets, M. Mathematical model of the thermal-air regime of a ventilated attic. J. Civ. Eng. Manag. 2015, 21, 710-719. [CrossRef]

15. Kilic, A.; Atis, C.; Yasar, E.; Ozcan, F. High-strength lightweight concrete made with scoria aggregate containing mineral admixtures. Cem. Concr. Res. 2003, 33, 1595-1599. [CrossRef]

16. Baltusnikas, A.; Siauciunas, R.; Lukosiute, I.; Baltakys, K.; Eisinas, A.; Kriukiene, R. Crystal structure refinement of synthetic pure gyrolite. Mater. Sci. 2015, 21, 111-116. [CrossRef]

17. Ryka, W.; Maliszewska, A. Petrographic Dictionary; Geological Publishers: Warsaw, Poland, 1982.

18. Birkenmjer, K. Lower Silesian basalt as monuments of inanimate nature. Nat. Prot. 1967, 32, $225-276$.

19. Kubiszewski, T. Similarities and differences in properties of gabbro and basalt aggregates. Stud. Mater. 2012, 41, 153-162.

20. Richardson, I. Tobermorite/jennite- and tobermorite/calcium hydroxide-based models for the structure of C-S-H: Applicability to hardened pastes of tricalcium silicate, beta-dicalcium silicate, Portland cement, and blends of Portland cement with blast-fumace slag, metakaolin, or silica fume. Cem. Concr. Res. 2004, 34, 1733-1777.

21. Oey, T.; Timmons, J.; Stutzman, P.; Bullard, J.; Balonis, M.; Bauchy, M.; Sant, G. An improved basis for characterizing the suitability of fly ash as a cement replacement agent. J. Am. Ceram. Soc. 2017, 100, 4785-4800. [CrossRef]

22. Available online: http://thermoddem.brgm.fr (accessed on 1 July 2019).

23. Gacki, F.; Feliks, J.; Wyszomirski, P. Research on the possibilities of using basalt dust waste. Inż. Ap. Chem. 2013, 52, 174-175.

24. Karwowska, J.; Łapko, A. The usefulness of using modern fibrobnetic composites in building constructions. Civ. Environ. Eng. 2011, 2, 41-46.

25. CEN. PN-EN 772-13: 2001 Methods of Test for Masonry Units-Part 13: Determination of the Density of the Net and Gross Density of Masonry in the Dry State (Except for Natural Stone); CEN: Brussels, Belgium, 2001.

26. CEN. PN-EN 1996-2: 2010 Eurocode 6-Design of Masonry Structures-Part 2: Design, Selection of Materials and Execution of Masonry; CEN: Brussels, Belgium, 2010.

27. CEN. PN-EN 771-2: Specification for Masonry Units. Part 2: Calcium Silicate Masonry Units; CEN: Brussels, Belgium, 2010.

28. CEN. PN-EN 772-11: Methods of Test for Masonry Units. Part 11: Determination of Water Absorption of Masonry with Aggregate Concrete, Artificial Stone and Natural Stone Caused by Capillary Water Absorption and Initial Masonry Ceramic; CEN: Brussels, Belgium, 2010.

29. CEN. PN-EN 772-1: 2011 Methods of Test for Masonry Units. Part 1: Determination of Compressive Strength; CEN: Brussels, Belgium, 2011.

30. Labus, M.; Such, P. Microstructural characteristics of wellbore cement and formation rocks under sequestration conditions. J. Pet. Sci. Eng. 2016, 138, 77-87. [CrossRef]

31. Wolfke, S. Technology of Lime-Sand Products; Arkady: Warsaw, Poland, 1986.

32. Nocun-Wczelik, W. Structure and the most important properties of selected hydrated calcium silicates. Ceramics 1999, 59, 17-32.

33. Handke, M.; Rokita, M.; Adamczyk, A. Crystallography and Crystallochemistry for Ceramists; AGH University of Science and Technology: Cracow, Poland, 2008.

34. Yan, J.; Zhao, C.Y. First-principle study of $\mathrm{CaO} / \mathrm{Ca}(\mathrm{OH})_{2}$ thermochemical energy storage system by $\mathrm{Li}$ or $\mathrm{Mg}$ cation doping. Chem. Eng. Sci. 2014, 117, 293-300. [CrossRef]

35. Lothenbach, B.; Kulik, D.A.; Matschei, T.; Balonis, M.; Baquerizo, L.; Dilnes, B.; Miron, J.D.; Myers, R.J. Cemdata18: A chemical thermodynamic database for hydrated Portland cements and alkali-activated materials. Cem. Concr. Res. 2019, 115, 472-506. [CrossRef]

36. Matschei, T.; Lothenbach, B.; Glasser, F.P. The role of calcium carbonate in cement hydration. Cem. Concr. Res. 2007, 37, 551-558. [CrossRef]

37. Reggiani, A. Innovative 2017 Geopolymer Products Prepared with Automatic Industrial Mixers. Available online: https://geomits.com/wp-content/uploads/2017/07/reggiani-geopolymer-products-prepared-withautomatic-industrial-mixers-geomits.pdf (accessed on 23 July 2019).

(C) 2019 by the authors. Licensee MDPI, Basel, Switzerland. This article is an open access article distributed under the terms and conditions of the Creative Commons Attribution (CC BY) license (http://creativecommons.org/licenses/by/4.0/). 